\begin{tabular}{l|l}
$\mathbf{m}$ & south \\
$\mathbf{m} \boldsymbol{n}$ & asia
\end{tabular}

samaj multidisciplinary

ui,u academic

III academic
South Asia Multidisciplinary Academic Journal

$12 \mid 2015$

On Names in South Asia: Iteration, (Im)propriety and Dissimulation

\title{
Remaining Nameless: Names, Hiding, and Dislocation Among Delhi's Runaways
}

Jonah Steinberg

\section{CpenEdition}

\section{Journals}

Electronic version

URL: http://journals.openedition.org/samaj/4061

DOI: 10.4000/samaj.4061

ISSN: 1960-6060

Publisher

Association pour la recherche sur l'Asie du Sud (ARAS)

Electronic reference

Jonah Steinberg, "Remaining Nameless: Names, Hiding, and Dislocation Among Delhi's Runaways », South Asia Multidisciplinary Academic Journal [Online], 12 | 2015, Online since 26 October 2015 connection on 06 May 2019. URL : http://journals.openedition.org/samaj/4061 ; DOI : 10.4000/ samaj.406

This text was automatically generated on 6 May 2019.

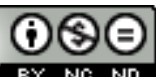

This work is licensed under a Creative Commons Attribution-NonCommercial-NoDerivatives 4.0 International License. 


\title{
Remaining Nameless: Names, Hiding, and Dislocation Among Delhi's Runaways
}

\author{
Jonah Steinberg
}

of the thought of the thought of the thought of his
name
his ineffable effable effanineffable
Deep and inscrutable singular name.

TS Eliot

1 This is an account of three ways Indian street-dwelling children, most of them runaways, use names to circumvent, play with, and navigate the constellations of power in which they move. These structures of power may govern both identity and physical existence, and include structures of production and consumption, nation-state, culture, space, and class-and the various places these forms collude and converge. For children unhitched from kin, who constitute in the public eye a kind of incomplete subject, and, in the administrative lens, a partial citizen, these disciplinary structures, far from fixed, allow for-or even invite-a great deal of play. The walls they mount are malleable.

2 One such mode of play comes in the form of hiding, of using various techniques of deception and dissimulation to obfuscate the pieces of identity that are rooted in originsin place, in kin, in former institutional iterations of self. For Indian child runaways, those origins are, in general, to be negated or refashioned. The origins are the locus of various forms of power, various intimate tyrannies, which the children have identified as oppressive and unfree and thus from which they have elected (usually) to run. ${ }^{1} \mathrm{~A}$ kind of narrative hiding is possible, or a hiding through narrative, and the irreducible, elemental kernel of that narrative is the personal name. Child runaways in North India engage names in exceptionally creative and complex ways to obscure former iterations of self. It is as though the street child, as runaway, is a new incarnation, an avātara ${ }^{2}$ with only a tenuous relationship to its past existences. 
3 And hiding from what, or whom? What could it possibly matter if some well- or illmeaning tourist or policeman knows if a child's name is (was) Ramsingh or Ashok or Amir Qalam?

4 Well, for one thing, it could: if (or once) registered by a charity or a governmental 'remand home,' child runaways appear in full-page newspaper advertisements, complete with mug shot and physical description. On June 1, 2007, for example, the Delhi Department of Woman and Child Welfare ran a full page notice in the Times of India with a banner identifying it as a list of 'Children Separated from Their Families.' Below the banner appear photographs of twenty-two boys; next to each photo, a phenotypic description, a place of putative origin, a nickname, and some auxiliary information:

THIS BOY RAKESH ALIAS TULSI S/O SHRI MAGAN, DABRI WAS ADMITTED IN THE ORGANIZATION ON 26.8.2004. AT THE TIME OF ADMISSION HIS AGE WAS AROUND EIGHT YEARS, HEIGHT 4 FEET 5 INCH, COMPLEXION DUSKY TO BLACKISH, BODY MEDIUM, FACE OVAL. IDENTIFICATION: A CUT ON LEFT LEG. ADDRESS AS TOLD BY THE BOY: VILLAGE BANTA NAGAR, DISTT. TATA NAGAR, BIHAR. ${ }^{3}$

THIS BOY JITENDRA KUMAR ALIAS BAJRANGI S/O SHRI ARJUN SINGH WAS AROUND 8 YEARS OLD AT THE TIME OF ADMISSION IN THE ORGANIZATION, COMPLEXION BLACK, FACE OVAL, PRESENT HEIGHT 4 FEET 6 INCH, IDENTIFICATION MARK: SCAR OF BURN NEAR RIGHT EYE. THE ADDRESS AS TOLD BY THE CHILD, VILLAGE JHUGGI, ${ }^{4}$ TWO K.M. AWAY FROM LUCKNOW, TEMPLE OF BAJRANG BALI, LUCKNOW, U.P. THE BOY WAS BROUGHT BY POLICE STATION NEW DELHI RAILWAY STATION ON 8.10.2003.

To evade being tracked, documented, represented, and located in spaces just such as this, children on India's streets often quite assiduously avoid interacting with charitable nongovernmental organizations (NGOs) that may collaborate with government agencies: these NGOs periodically put children at the center of vigorous and pointed campaigns aimed at what is termed 'repatriation,' bringing the child back home based on the notion or belief that home is necessarily the place where children should be, and is always better than 'the street,' even if in campaigns to 'getting children off the street' it is not clear whether it is the aesthetics of the street or the child's taint that is in question (see Hecht 2000, Scheper-Hughes \& Hoffman 1998 on the cleansings of the street that target street children). As an ethnographer, I usually had to convince the runaways with whom I worked that I had nothing to do with any of these organizations and that no particular information that would identify them would make it back to said NGOs.

5 Here, then, the three modes of engaging with names/namelessness I problematize, and that are especially captivating, are as follows: (1) the aforementioned adoption of selffashioned conventional names, often crossing communal boundaries, as a piece of protecting identity and in general enjoying the notion of untrackability; (2) the assignment (usually self-embraced) of names denoting some identifiable embodied feature-a missing limb, dark skin, an unusual body shape; and (3) a complex and poignant strategic use of categorical historically-determined names for 'urchins' and 'vagabonds.' I want to think on how the variable use of such categorical names suggests an inchoate collective consciousness of shared structural experience-and a corresponding solidarity that can, as with the duplicitous use of personal names, be tied to the same particular relationship to systems that record and enumerate, from newspapers to police forces, families to children's shelters-that shapes the complex dissimulative use of names of every sort, personal, ascriptive, and collective. 


\section{Locating the Typified Runaway}

6 I am obliged to say more about who the proverbial runaway I am describing is-a necessarily broad generalization of a type that emerges on what the public calls the 'streets,' even if it is precisely such broad generalizations that fail to accord these people the right to name themselves.

7 In North Indian cities, a significant proportion of street children are runaways from rural villages. Many of these young runaways frame their departure from the village for the city as an active, intentional choice (McFadyen 2004; Conticini \& Hulme 2007). Moreover, in most cases, children frame their own decisions to run away as a socially-accepted life option. At the heart of the ethnographer's proposition that running away does represent a timeworn and accepted life option, if she is to take the runaway's own stories seriously, is a concern with a set of historical conditions, a certain intersection of political economy and domestic crisis (Wallerstein 2004:37; Jodhka 2003), which could make such an experience seem ordinary and normal. I suggest that colonialism, industrial capitalism, and globalization have produced radical transformations of the countryside-for example in the colonial period via indigo (see Pouchepadass 1999) or later via the green revolution (Cullather 2010)-and of the relationship of the rural to the urban through histories of labor and the railway (see Prakash 1990, Bear 2007, Aguiar 2011), which profoundly impact children's experiences in the domestic sphere and in the local community. Thus it is not critical poverty itself from which children flee, but rather the oblique impact of routinized and normalized disparities of wealth on homes and emotional lives. As Conticini and Hulme (2007) observe of (largely runaway) street children in Bangladesh: 'the breakdown of social relationships within the household, and not economic poverty, is the main cause of child migration to the street' (207). Consider the following arrival narrative from an adolescent runaway from New Delhi Railway Station I will refer to as Naushad. The V in the interview is 'Vikas,' J is the author, and K is the author's research partner, Khushboo.

J: Did you run away? How old were you?

$\mathrm{N}$ : Five years old, in second grade when I was five.

$\mathrm{J}$ : What about you?

$\mathrm{V}$ : I came in anger.

J: From Himachal too?

$\mathrm{V}$ : No not from Himachal.

J: How did you know that you could take a train?

$\mathrm{N}$ : My house was as close to the station as this station is to Paharganj. My house. I just thought of taking a train and going a little ways. I didn't know that the train was going to drop me at Delhi. It took me a day and a half to reach here. I got down from the train, I got out at the station, there was a water seller and he offered me some water and some chhola kulcha, and I started collecting bottles and studying a little bit with a very good didi. I did some good studies and then that didi stopped coming. I kept collecting bottles and collecting bottles and then I started to feel ashamed about that act.

K: Weren't you scared when you left home, being so young?

$\mathrm{N}$ : What fear? I came because I was angry. I didn't leave with any idea of whether I would return or not. I just came out with the idea that my parents would get worried, look for me and then I would eventually return. I thought that they would become frightened for me and stop beating me and love me. I left home with this thought. 


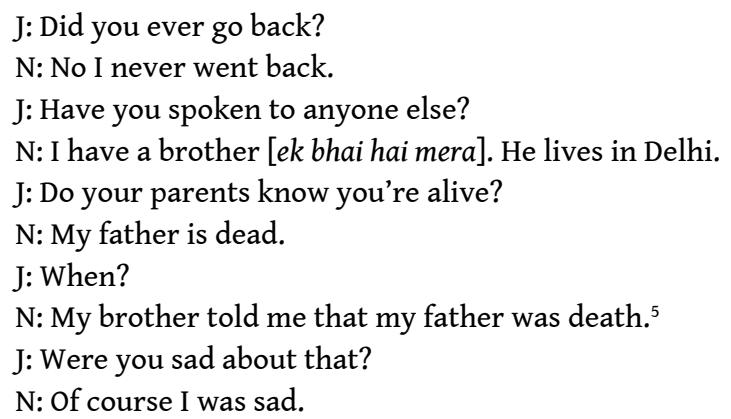

8 Running away is certainly a key process in the formation of populations of street children worldwide (Dos Santos 2002; Conticini \& Hulme 2007), but it appears more common in South Asia than elsewhere. Street children's journeys may shed important light on more fundamental issues surrounding childhood, especially on how children respond to family stresses brought on by larger processes of political economy, how children express intentionality in the face of domestic violence and overwhelming work expectations (see Conticini \& Hulme 2007; Karlekar 2003; Nieuwenhuys 1994; McFadyen 2004; Margolin \& Gordis 2000), and how children behave in the absence of the expected sources of adult supervision. Running away in epistemological contexts, for their part, contravenes the expectations of Indian and global institutions and ideologies which prescribe what a 'proper' or 'correct' childhood constitutes. Other categories of street children, including those who live with their families, or those like orphans who are on the street due to circumstances beyond their control, do not necessarily defy such prescriptive visions of childhood.

Above all, what is legible (or at least faintly discernible) in runaways' tracks, transits, and trajectories is a kind of drastic transformation of rural social fabrics, enacted most fundamentally through debt, which comes to life in family stresses and an alternative to which (or escape from which) is given form in the very threads of industry and postcolonial anomie which were part of its production-the channels of railway, labor migration, and postcolonial itinerancy as a strategy of evasion.

\section{Methods}

10 This research was conducted as part of a four-year, NSF supported project, ${ }^{6}$ ethnographic fieldwork for which was intensive. Research covered some 20-25 distinct sites in New Delhi, in all cases repeatedly and in most frequently; and some 25-30 sites across India, in many cases repeatedly and in some frequently. The core concern of the research was to ascertain the key determinants and antecedents underlying children's decisions to run away from home, to identify the circulation of discourses on and of running away, and to locate historical factors that can be correlated to differential frequencies in solo childhood departures from home.

11 Primary sites in Delhi included Hazrat Nizamuddin Shrine, Hazrat Nizamuddin Railway Station, New Delhi Railway Station, Old Delhi Railway Station, Okhla Mandi, Vasant Vihar Market, Jama Masjid, Hanuman Mandir, Yamuna Bazaar and Peti Market, Meena Bazaar, Matia Mahal, Mehrauli, Connaught Place, Anand Vihar, and many others. Primary sites across India, with the support of Khushboo Jain, included villages, towns, and cities in Bihar, Jharkhand, Uttar Pradesh, West Bengal, Maharashtra, Orissa, Rajasthan, Kerala, Tamil Nadu, and many other sites. City studies were carried out in Lucknow, Calcutta, 
Mumbai, Malda, Patna, Ranchi and Cochin. Data collected in these sites incorporates interview material, spontaneous conversation, documentation of movement patterns, elicitation of life stories, demographic surveys, organizational archives, imperial archives, and much more. Observation was also made of individual runaways over time to ensure the longitudinal integrity of the project, which fostered the development of a broad understanding of the historical antecedents of running away, in particular as regards landlessness, credit relations, and multiple forms of rural debt. Other major lines of inquiry developed over the course of the research included an exploration of the role of industrial-era railroads in the process of running away, of experiences of death and loss as a factor in departure, and of interaction with charitable and governmental institutions. 'Tribal' identity has emerged as a major determinant among runaway populations. Living patterns and spatial dynamics in railway stations and elsewhere proved a complex and interesting feature of runaways' lives.

\section{Naming Danger. The Urgency of Counternymic Evasion}

blessing to come to the city. They've left domestic and local traumas and crises and fled to a situation they see as better, for all its stress, risk, and hardship. And so once there, they do not want to be tracked, do not want to be returned to their families, and they seek what they themselves term freedom. It is certainly not anonymity they are seeking, though that term is surely what society-at-large, and even scholarly observers would use -for indeed they seek, they embrace the having of a name, just not the one that is given them by the ossified forms that trapped them before, forms of patriarchal kinship and marriage, intimate force, discipline and labor. It is, rather, the active engagement of what might be termed a counter-nymic (or anti-nymic) praxis, wherein names are the domain of active and defiant authoring. This is, indeed, a form of evasive mobility, I suppose, of a sort. A 'nomadics'-not spatial, but discursive. Foucault (1995) highlights the operation of power at the intersection of mobility and fixity, noting that 'one of the primary objects of discipline is to fix; it is an anti-nomadic technique' (218). Deleuze and Guattari's 'nomadology' (1987), further, imagines a new and more fluid relationship between subject and territory, wherein the typified 'nomads' fashion their own space. However, the mobility or nomadology enacted by runaways is far more profoundly rooted in material conditions and the set of possible responses thereto (escape, resistance, evasion) than the sort of fluidity envisioned by Deleuze and Guattari.

14 And indeed this assertion is nothing without historicization. And for this to be historicized, the very forces that motivate such a mandate must themselves be named: the state, for example, in myriad forms, including child prisons, 'welfare services,' and murky forms of legal registration, including the Juvenile Justice Board; private charities that vigorously pursue programs of class socialization, integration, and confinement, sometimes working at the behest of the state; the police at their various levels (municipal, military, etc.); religious functionaries seeking various forms of ideological engagement in exchange for services provided; traffickers; pimps; slave-runners; parents. All these present various forceful mandates for hiding. 
In this calculus (or constellation) of age, power, and place, personal names fix and assign, they threaten to confine and block mobility, and they locate, in what Matt Hull (2012) calls the 'government of paper,' albeit with a rather grand disorganization, and they further escape the sorts of conceptual and spatial slots to which children were newly assigned or confined with the advent of colonial blueprints of childhood in India in schools and elsewhere (see Sen 2005 and Balagopalan 2014). They do what Anderson (1992) observed of the census, the map, and the museum-they enumerate. Simultaneously, however, categorical names produce the possibility for solidarity, coacknowledgment, some kind of protection in numbers, a sense of collective self through a naming of 'what we are,' and perhaps even a nascent notion of both subjection and resistance. So while in some ways solo children's use of names comes down to a non-use of names, or a use of non-names, to escape the arresting gaze and grasp of discipline, the predations of forces that seek to fix, in others it underscores a denotation of categories that are never the terms of classification.

As flight and escape, particularly from untenable domestic situations, is itself at the very center of their stories of self, NGOs, government programs of 'child rescue,' and serviceproviding religious institutions are seen simply to replicate the uncomfortable confinement from which they ran and the common wisdom is thus to avoid them. As any agent in public space threatens to temper their mobility and freedom, and potentially to make their location known to forces they wish to evade, these runaways may use dozens of names. The names are not used in unpatterned ways, but rather they are situationallycontingent. A child may vary its name by location, or by occupational situation, or by the age or other category of their conversational partner.

This, then, lays out the contextual cartography for the children's complex set of deeply situational naming strategies-both for themselves as individuals and for the category of person to which they see themselves belonging-as a component of anti-disciplinary strategies of evasion, dissimulation, and self-protection. In this widely-replicated mode of narrative praxis, iterated in similar ways throughout the Subcontinent (and beyond), personal names as deployed by 'street children' become fluid vehicles of strategic selfpositioning to circumvent forms of power that seek to define, fix, and track the children.

\section{The Physical Counterpart: Transi(en)t Space}

This practice of nominal hiding and self-obfuscation corresponds to a wider tactic of actual, physical-indeed cartographic-hiding mounted by these children, for a microcosm of which I will let my narrative settle some on the railway stations in which they reside. The description of this process is a necessary counterpart to the assertion that counternymic evasion is part of a materially-iterated calculus (that must go beyond the semiotics of Deleuze and Guattari's nomadisms), and can be rendered legible in space as well as in language. I describe this material evasion, in other words, because I believe it is part of a wider complex with-and has powerful counterparts in-the more intimate hidings of language and names that I describe.

The children's living is indeed structured by the very notion of hiding. While in the interior of the edges of the stations they live in-and, in this case, of Hazrat Nizamuddin Railway Station-are the designated spaces of the proper and prescribed subjects (or agents) of railway space, including the Railway Protection Force, engineers, train 
operators, military security (present in force with machine guns) and other staff, children keep away from such legitimate compartmentalization (see again Bear 2007, Aguiar 2011). Even menial labor, whose portering work is formalized in stations, have their own designated location marked with a sign reading 'Coolie Shelter." Solo children, however, for whom there is nowhere they are explicitly allowed to be, or supposed to be, must forge of the station's space transgressive zones in which they can move and subsist evasively. This legal and disciplinary conundrum is part of what requires resistance, or transforms just-living into resistance, and defiance of the sort that mounts a challenge to disciplinary spatialities. Everyone legitimate has a 'proper place'; even the poorest laborers are legitimate. But for the few subjects who have no proper place, being anywhere is legible as the contestation of a space. To accord them a place in the station would be to acknowledge the legality of child labor and of the failure of welfare, to point to the perceived failures of a nation, and to highlight aesthetics that the city and the state, modern, corporate, Asian, and clean as they envision themselves, would rather not dignify with comment or deixis. It must be added that the praxis of hiding must be balanced rather carefully with a measured and intentional visibility, to be deployed for example when begging.

At Hazrat Nizamuddin Railway Station, the primary group with which I worked lived in a nearly-invisible spot between two inward-sloping segments of corrugated tin roofing that runs along the platform, and underneath the footbridge that spans the station, from whose lateral lattice it must be accessed. The group-all of whom had replacement names, often transecting and transcending communal boundaries-slept, ate, huffed, snuggled, and sorted in that location. Roof living is a favorite way to avoid police and hostile passengers. Jamshed, a grown runaway who at the time of my research worked for an NGO, recounts that his group lived for years in a spot of roofing in New Delhi Railway Station that they called, simply, 'our place.' Consider for ethnographic context Jamshed's distinctive arrival narrative, in which he explains that he didn't 'come' to Delhi. That would be too intentional a characterization. Here is how he recounts it:

I was taken.

I was with my friends. I was excited to see Delhi, to know new things. Delhi is different from the countryside, you know. People in my village always talked about how great Delhi was. So I said: I'm going.

I did not come on my own. I had some friends, they had some railway tickets. They wanted to go for vacation, for eleven days. Come to Delhi, they said, Delhi is great, there are strange things there, there's a lot of electricity there [i.e. 'it is an electric sort of place'], so I became very excited. I came with my friends, and then they abandoned me [on the train]. I had no idea what Delhi was, I was totally senseless [ i.e. 'bewildered'].

So when the train stopped, some people said we're getting to Delhi, it's the last stop. And I got off.

I saw how different everything was, what my nation is like. On my first night I slept on the platform. In the morning I met some other kids. I was hungry. I saw some of them eating. You see, they noticed me because I was well-dressed when I first came. And I lived in the station two years. ${ }^{8}$

21 I worked with a group in the same station that lived hidden beneath the stairs near the bathrooms on the Delhi Gate side. The primary living, waste-sorting and sleeping location for children in New Delhi Station (NDLS), however, is the so-called jali. A jali is a lattice or screen, but it also represents seclusion, secrecy, status, and purdah in Indo-Islamic architecture and literature, and is thus of great symbolic importance in collective imaginaries of space; it represents a certain cultural read of the station. This particular 
jali, however, happens to be a screen (or a grill) enclosing an electrical grid or substation (a high-voltage power supply, in fact, to feed overhead catenaries), but hiding the children, including, once, Petu-'Tummyboy'-who was mangled and died beneath the Rajdhani Express; the children's sleeping area was in the space between the screen and the grid it protected. Despite (my) safety concerns, it seemed to serve its role as a jali in the domestic and cultural sense, bestowing a degree of seclusion, separation, security, and privacy within its forbidding perimeters.

Beyond this compartmentalized officiality, and past the tracks' edges, more secrecy: there lie the stations' borderlands and shadow zones: dumps, scrubland, makeshift croplands, sewage swamps. At Hazrat Nizamuddin, this zone contains a vacant lot that is called 'the Park.' While lounging around the inside of an inactive train one afternoon with some eight or nine of the boys, who wanted a solvent-sniffing rest after some tiring scavenging, I asked, after a mention of someone who had gone to the Park, 'what happens there?' Raju, with whom I worked intensively at Nizamuddin, a Rajasthani runaway or orphan (who kept his story secret) who had himself changed his name to this sobriquet (or, really, one similar to it) from a Muslim name (let's say Irfan), looked away, and said, in a hushed voice, 'sexy' (i.e. sex). Perhaps over-reading his candor and comfort at the question I then later asked if he might repeat what he had said, to open it up for comment by the other boys, and for my research partner, Khushboo, to hear. But he declined, not surprisingly, and would not elaborate.

In such a way, it might suddenly dawn on us that the hiding place works not only for but also against the hiders, the children; on the one hand, it allows evasion, resistance, concealment. On the other hand, however, it allows others to hide their exploitive interactions with the children, to conceal what they do to them in the hiding places. What then would be the salience for the politics of pseudonymity? The same: where fluid names allow for a certain sorcery of self-obfuscation, they also work against the children in denying them any legal locatability: a child with many or no names, or conjured names, can be preyed upon with greater impunity, for the recourse they might seek is negated by their invisibility, their inability to exist, in a legal sense; in the absence of a name, there shall be no record of whatever is to be done to them by this-or-that petty tyrant-rape, enslavement, trafficking, forced begging-and the tyrant in question can sit comfortably with the knowledge that this child can barely be said to exist-certainly not sufficiently to mount a grievance or even to be found or to be heard from again if a threat (or worse) should be articulated. After all, s/he has given up the last claim on legal location, enumeration, existence: the name.

\section{Of Vagabonds and Skeleton Children}

The children's own language, and in particular the terms they use to describe themselves and their peers, must rest at the heart of this reflection. Even ethnographers reinforce society's indifference to children, their perception as non-citizens, as unformed beings, by forever consulting adults on the nature of society and space. But children are people of unique and varied perspective; if scholars insist that institutions and homes must take them seriously, so must they take seriously the idea of children as possessors of an unparalleled social vantage and an experience and interpretive toolkit like none other. 
25 In North India, three primary terms for 'street child' are in daily circulation among the children and others: aawara, lawaaris and kangaal (sometimes in compound conjunction with baccha, 'child,' i.e. lawaaris baccha). The historical etymologies of these terms are captivating, given their referents and the contexts of their usage. In general, these terms, despite the more specific denotations suggested by their morphologies, are abstracted from situational type, so any of them might be used in equal measure for an orphan, a runaway, a street-working child with family nearby, or an abandoned child.

26 Of the three terms, only kangaal, for which Platt (1884) gives 'poor,' 'wretched,' 'miserable,' indigent,' 'beggarly,' etc., appears to be of unambiguous Indic origin. Though mobilized by the children to describe themselves and others like them with relative frequency, it is also the most rarely used of the triad. Platt provides a historical derivation of Prakrit kankalo, 'skull,' and Sanskrit kangkala, 'bone garland'9 or 'skeleton'implicitly denoting a form that is already dead or half-dead. Given their heightened susceptibility to death, much might be made of the application to street children of a term which ties them, as animate skeletons, to living death. Bone children.

27 The colloquial denotation of lawaaris, whose formal translation in Hindi is 'unclaimed,' is 'orphan' or 'waif.' The term's compound derivation is from Arabic: la- 'no' + waaris (or waarith) 'successor': thus, fundamentally, 'kinless' (and at the end of a lineage). This again points poignantly to something fundamental in the calculus of child vagabondage: kinlessness. Kinlessness, alongside a complex relationship to family, figures prominently both into the empirical features of the life course of the children who eventually are assigned the 'street child' identity and into their perception by wider publics. Kinlessness is a core trope of runaway self-fashioning, and indeed it is a certain dialectic with kinship that renders the runaway socially and publicly legible as a certain category of person.

28 The third term, aawaara, is of uncertain origin, though the derivation is likely Persian. Platt (1884) gives 'separated from one's family; without house and home; wandering, roving; astray; abandoned, lost; dissolute' and 'vagabond.' To try to discover more about the term's origins, I surveyed some of the world's leading Indo-Iranian historical linguists. Claus Zoller, Richard Frye, and Edmund Bosworth concurred with the Persian origin. Berkeley's Martin Schwartz suggests 'the word is unquestionably Persian,' but of unclear etymology; Nicholas Sims-Williams says the same. Schwartz gives a meaning of 'vagrant, displaced, exiled, outcast, mistreated.' Eden Naby Frye points out that it is attested in modern Aramaic, writing:

I am a native modern Aramaic speaker from Northwest Iran and aawaara was/is a common term in my vocabulary. It is definitely negative and ranges in meaning from astonished to confused. Oraham's dictionary p. 12 col. b. defines the term as Wandering; a wanderer; a vagrant or listless person. I would use it thus: A danta'd chashmu shmidlun, pishle avaara. When his glasses broke, he became confused. Or, the children became wanderers, going from village to village when their parents died.

Christopher Brunner, further, points to the word's emergence specifically in New Persian. ${ }^{10}$ Elizabeth Tucker, in her personal communication asked: 'is there any chance that the word is awaara or awaaaraa with short initial $a$ - ? [...] If so, according to Turner, these words continue Sanskrit and Pali apaara- , Prakrit avaara- "boundless, without boundaries".'

What is notable about the results of this playful little concordance on the long trajectory taken by the names the children use for themselves and each other is that they assign the 
children to timeworn, historically-circumscribed categories, categories that have clearlyalong with their names and accompanying tropes-been around a long time. Indeed, though the criticism might be made that the children appear to know or comment very little on such matters, they in fact do: they joke on the meaning of names, reflect on their position in politics, the state, the world, ruminate on their abandonment by society, its meaning, its cruel ironies. It is not likely that the use of such terms to describe such children is new. Moreover, it is remarkable that the terms name features of these children's lives that are basic, fundamental, and true elements of their stories and trajectories, and also of their social valency: vagrancy, vagabondage, mobility, mendicancy, the experience of being lost, abstraction and separation from kin, existence at the edge of society, proximity and susceptibility to death. The lexicon reveals a certain rootedness in cultural paradigms for such children. It is unclear why this is the case, or how it came to be, but reading into the implications of these names proves at the very least a window into the construction of emergent understandings of shared self.

\section{No-Body: On the Somatics of Naming}

There was, for a time, in the vicinity of Delhi's Prachin Hanuman Mandir (the temple to the Monkey God near the Yamuna River), a twelve-year-old runaway whose name was Nabil. of the street-dwellers of that quarter, many would know him, if you asked, but not by that name: he's known only by Toonda, which denotes the arm he lost to a train that backed up on it.

Excuse me, I once said, looking for him, is Nabil here?

Nabil?

You know, kid from Bangladesh, kid with only one arm?

Ohh-Toonda. Yeah, he's around.

Toonda, it seems, can mean 'imbecile,' 'half-wit,' or 'idiot,' though it can also mean (most famously in the case of the notorious militant bomb-maker Syed Abdul Karim, 'Tunda') handicapped or even 'handless.' Somehow, in the context of the first definition set, the missing arm, the bodily mutilation, renders Nabil a dunce; his bodily form is equated with a kind of intellectual handicap, which gives him a social stigma (but also prestige, cachet) he cannot shake. And yet, curiously, perhaps because it is intended ironically, he seems not to want to shake his nickname. It is a name that Nabil embraces; and it even occupies a peculiar place of pride at the center of his identity and sense of self.

When I met Nabil, in the winter of 2011, he was perhaps twelve. For a time he returned to his home in Bangladesh, where he broke it to his mother that he'd become, sociallyspeaking, a cripple, a task which he'd been dreading terribly. He returned to the street the following year a bigger boy, a full-fledged adolescent, but still not Nabil.

Not far away, in that same season, I came with my assistant, Khushboo, upon the mangled body of another runaway child, only nine or ten, who'd only minutes before died beneath a train. Flies swarmed and vultures circled above the tracks where his corpse laid, alongside his severed legs and feet. As we waited for the police to arrive to begin the mortuary process, we learned from the other railway children a bit more about this child, but we could not uncover his true name, for he was known only as Petu-Tummyboy. When this story at length wended its way into the courts and the press, he remained Petu. Later, when we learned his real name was (let's say) Rahul, when we looked back at the photos of his body, we surmised his moniker had come from the long scar on his stomach. 

a social milieu; in this case, correspondingly, the body emerges the most immediate field for the reading of self. And thus, in a field (a field indeed quite distant from Bourdieu's $(1985,1986)$ field of embodied habitus) with little displayable or durable capital, what is worn on, revealed by, or achieved with a body becomes absolutely central to the construction of self and status. Where even names and biographies are fluid and contingent, body becomes itself a perduring site for spinning names and corresponding personhood narratives.

\section{Effanineffable: Names and the Claim to Self} deploys names as a way to stake a claim to the ownership of her own story.

To wit: there was a boy who inhabited among the other homeless the park at the center of Delhi's largest mosque, the Jama Masjid. All the other runaways knew him, and in his long career here he went in and out of multiple charities and homes many times. I was able to identify at least four separate major NGOs, each of which processes thousands of cases, in which he was known-and in each he had a different name, and each a different story. I knew the boy both as (let's say) Akhil and, simultaneously (let's say), Aziz. And I do note that the politics of the IRB requires me to perform my own dissimulation of names. As the story goes, Akhil ran away very young. As he told it, he was sold off multiple times, first to a tea seller, then a roadside snackmaker, who sold him off again, and so on, for a few hundred rupees each time. In some versions of Aziz-Akhil's self, he originated in rural Bihar or Uttar Pradesh. In others, he'd come from within Delhi's limits. He'd run away from each NGO he'd been sheltered by. A Hindu social worker at the NGO 'Butterflies'

South Asia Multidisciplinary Academic Journal, 12 | 2015 
registered him as Akhil because she did not want to give him a Muslim name, and Akhil stuck as his sometimes-name.

Similar stories emerge all over the landscape of street-dwelling children: like that of a girl in New Delhi Railway Station I met, once, with at least four names, most of them carrying a sort of mythic texture-several of them indeed consorts of the Major Gods. And indeed children throughout India, and across South Asia, invariably dissimulate like this, at least initially.

Why is it that Akhil-Aziz does not want his true name known? What threat does that pose? Again we return to the essential geometry of names at the nexus of self, past, locatability, and power. Akhil-Aziz probably knows quite rightly that dissimulation and deception keeps him untrackable, unlocatable, and that his name and origin threaten to send him, well, home, or somewhere else where he can't move as he wants. He does not wish to occupy registers and logs, does not care to be put in a home, does not want to be surveilled across the land, does not want to inhabit a line in Hull's (2012) proverbial file. Wherever it is he comes from, Akhil-Aziz does not want to go back there. Wherever it is someone might take him, neither does he want to go there.

Perhaps, in terms derived from one of poetic motifs I've dwelt upon, from Deleuze and Guattari, Akhil-Aziz is practicing an active and very intentional narrative nomadics, a practice of non-fixity, of flexibility, of fluidity, of never being kept sur place, matched by a much more tangible, much more material practice of evasion and defiance, perhaps along the lines of the urban and spatial struggles Harvey (1985, for example) and Lefebvre (1975) propose-for children too, as invisible and voiceless subjects par excellence, are capable of mounting such resistances, and they should be seen to be so. In such ways names may be used to confound the power of the state and the authority of the city to arrest movement, to count, to achieve perfect surveillance. Remarkable, to think that in a world of potent rebels, smugglers, and movements, it is perhaps a set of barely-noticed children who might best disrupt regnant machineries and orders, and the normative ideologies upon which they rest. The 'vagabond' child, in the murky and inchoate space between actively-deployed collective names and actively-hidden personal names, blurs the categories that render a human being a subject of a certain type, and achieves an evasive resistance at the edge of the city's powers, a shadow zone of kinless autonomy far from institutional walls in which selves may be reauthored and refashioned with some considerable freedom.

\section{BIBLIOGRAPHY}

Abadía-Barrero, César E. (2002) 'Growing Up in a World with AIDS: Social Advantages of Having AIDS in Brazil', AIDS Care, 14(3), pp. 417-23.

Agha, Asif (2007) Language and Social Relations, Cambridge: Cambridge University Press.

Aguiar, Marian (2011) Tracking Modernity: India's Railway and the Culture of Mobility, Minneapolis: University of Minnesota Press. 
Ahearn, Laura (2000) ‘Agency', Journal of Linguistic Anthropology, 9(1-2), pp. 12-15.

Aptekar, Lewis (1988) Street Children of Cali, Durham: Duke University Press.

Ariès, Philippe (1962) Centuries of Childhood: A Social History of Family Life, New York: Vintage Books.

Baker, Rachel; Panter-Brick, Catherine (2000) 'A Comparative Perspective on Children's 'Careers' and Abandonment in Nepal', in Catherine Panter-Brick \& Malcolm T. Smith (eds.), Abandoned Children, Cambridge: Cambridge University Press, pp. 161-81.

Balagopalan, Sarada (2014) Inhabiting 'Childhood': Children, Labour, and Schooling in Postcolonial India, London: Palgrave.

Bear, Laura (2007) Lines of the Nation: Indian Railway Workers, Bureaucracy, and the Intimate Historical Self, New York: Columbia.

Bourgois, Philippe (1998) 'Families and Children in Pain in the U.S. Inner City', in Nancy ScheperHughes and Carolyn Sargent (eds.), Small Wars: The Cultural Politics of Childhood, Berkeley:

University of California Press, pp. 331-51.

Bourdieu, Pierre (1977) Outline of a Theory of Practice, Cambridge: Cambridge University Press.

Bourdieu, Pierre (1986) 'The Forms of Capital', in John Richardson (ed.), Handbook of Theory and Research for the Sociology of Education, New York: Greenwood Press, pp. 241-58.

Boyden, Jo; Ennew, Judith (1997) Children in Focus: A Manual for Participatory Research, Stockholm: Rädda Barnen.

Breman, Jan (2003) 'The Informal Sector', in Veena Das, Andre Beteille \& T.N. Madan (eds.), The Oxford India Companion to Sociology and Anthropology, Oxford: Oxford University Press, pp. 1287318.

Campos, Regina; Raffaelli, Marcela; Ude, Walter (2008) 'Social Networks and Daily Activities of Street Youth in Belo Horizonte, Brazil', Child Development, 65(2), pp. 319-330.

Chakrabarty, Dipesh (1991) 'Open Space/Public Place: Garbage, Modernity and India', South Asia, 14(1), pp. 15-32.

Conticini, Alessandro (2008) 'Surfing in the Air: A Grounded Theory of the Dynamics of Street Life and its Policy Implications', Journal of International Development, 20(4), pp. 413-36.

Conticini, Alessandro; Hulme, David (2007) 'Escaping Violence, Seeking Freedom: Why Children in Bangladesh Migrate to the Street', Development and Change, 38(2), pp. 201-27.

Cullather, Nick (2010) The Hungry World: America's Cold War Battle Against Poverty in Asia, Cambridge (Massachusetts): Harvard University Press.

Cunningham, Hugh (1991) The Children of the Poor: Representations of Childhood Since the Seventeenth Century, Cambridge (Massachusetts): Blackwell.

Cunningham, Hugh (2006) The Invention of Childhood, London: BBC Books.

Cunningham, Hugh (1995) Children and Childhood in Western Society Since 1500, London: Longman.

Deleuze, Giles; Guattari, Félix (1987) A Thousand Plateaus: Capitalism and Schizophrenia, Minneapolis: University of Minnesota Press.

Dos Santos, Benedito Rodrigues (2002) Ungovernable Children: Runaways, Homeless Youths, and Street Children in New York and São Paolo, PhD dissertation, University of California at Berkeley.

Ennew Judith (1994) Street and Working Children: A Guide to Planning, London: Save the Children Fund. 
Farmer, Paul (1997) 'On Suffering and Structural Violence: The View from Below', in Arthur Kleinman, Veena Das \& Margaret Lock (eds.), Social Suffering, Berkeley: University of California Press, pp. 261-83

Finkelstein, Marni (2005) With No Direction Home: Homeless Youth on the Road and in the Streets, Belmont (California): Thomson Wadsworth.

Foucault, Michel (1995) Discipline and Punish: The Birth of the Prison, New York: Vintage.

Ganguly-Scrase, Ruchira (2007) 'Victims and Agents: Young People's Understanding of Their Social World in an Urban Neighbourhood in India', Young, 15, pp. 321-41.

Gigengack, Roy (2008) 'Critical Omissions: How Street Children Studies Can Address SelfDestructive Agency', in Pia Monrad Christensen \& Allison James (eds.), Research With Children, London: Routledge, pp. 205-19.

Glauser, Benno (1997) 'Street Children: Deconstructing a Construct', in Allison James \& Alan Prout (eds.), Constructing and Reconstructing Childhood: Contemporary Issues in the Sociological Study of Childhood, London: Falmer Press, pp. 145-64.

Goldstein, Donna M. (1998) 'Nothing Bad Intended: Child Discipline, Punishment, and Survival in a Shantytown in Rio de Janeiro, Brazil', in Nancy Scheper-Hughes \& Carolyn Sargent (eds.), Small Wars: The Cultural Politics of Childhood, Berkeley: University of California Press, pp. 389-415.

Gough, Katherine and Monica Franch (2005) 'Spaces of the Street: Socio-Spatial Mobility and Exclusion of Youth in Recife', Children's Geographies, 3(3), pp. 149-66.

Grew, Raymond (2005) ‘On Seeking Global History’s Inner Child', Journal of Social History, 38, pp. 849-58.

Gupta, Narayani (2003) 'The Indian City', in Veena Das, Andre Beteille \& T.N. Madan (eds.), The Oxford India Companion to Sociology and Anthropology, Oxford: Oxford University Press, pp. 458-76.

Hart, R. A. (1992) Children's Participation. London: United Nations Children's Fund/Earthscan. Harvey, David (1985) The Urban Experience, Baltimore: Johns Hopkins.

Hect, Tobias (1998) At Home in the Streets: Street Children of Northeast Brazil, Cambridge: Cambridge University Press.

Hecht, Tobias (2000) 'In Search of Brazil's Street Children', in Catherine Panter-Brick \& Malcolm T. Smith (eds.), Abandoned Children, Cambridge: Cambridge University Press, pp. 146-60.

Heywood, Colin (2002) A History of Childhood, London: Polity.

Huberman, Jenny (2012) Ambivalent Encounters: Childhood, Tourism, and Social Change in Banaras, India, Trenton: Rutgers University Press.

Hull, Matthew (2012) Government of Paper: The Materiality of Bureaucracy in Urban Pakistan, Berkeley: University of California Press.

Jenks, Chris (2005) Childhood, $2^{\text {nd }}$ ed., London: Routledge.

Jodhka, Surinder (2003) 'Agrarian Structures and Their Transformations', in Veena Das, Andre Beteille \& T.N. Madan (eds.), The Oxford India Companion to Sociology and Anthropology, Oxford: Oxford University Press, pp. 1213-242.

Karlekar, Malavika (2003) 'Domestic Violence', in Veena Das, Andre Beteille \& T.N. Madan (eds.), The Oxford India Companion to Sociology and Anthropology, Oxford: Oxford University Press, pp. 1127-157. 
Kilbride, Philip; Njeru, Enos; Suda, Collete (2000) Voices of Children in Search of a Childhood, Westport (Connecticut): Bergin \& Garvey.

Korbin, Jill E. (2003) 'Children, Childhoods, and Violence', Annual Review of Anthropology, 32, pp. 431-46.

Kovats-Bernat, J. Christopher (2006) Sleeping Rough in Port-au-Prince: An Ethnography of Street Children and Violence in Haiti, Gainesville: University Press of Florida.

Lancy, David (2008) The Anthropology of Childhood: Cherubs, Chattel, Changelings, Cambridge: Cambridge University Press.

LeFebvre, Henri (1974) La Production de L’Espace, Paris: Editions Anthropos.

Legg, Stephen (2007) Spaces of Colonialism: Delhi's Urban Governmentalities, Oxford: Blackwell. Lewnes, Alexia (2001) Misplaced: New York City's Street Children, New York: Xenium Press.

Lucchini, Riccardo (1996a) ‘The Street and its Image’, Childhood, 3(2), pp. 235-46.

Lucchini, Riccardo (1996b) 'Theory, Method and Triangulation in the Study of Street Children', Childhood, 3(2) (1996b), pp. 167-70.

Margolin, Gayla; Gordon, Elana B. (2000) 'The Effects of Family and Community Violence on Children', Annual Review of Psychology, 51, pp. 445-79.

McFadyen, Lori (2004) Voices from the Street: An Ethnography of Indian Street Children, Delhi: Hope India Publications.

Mickelson, Roslyn Arlin (ed.) (2000) Children on the Streets of the Americas: Globalization, Homelessness and Education in the United States, Brazil and Cuba, London: Routledge.

Moncrieffe, Joy (2007) 'When Labels Stigmatize: Encounters with "Street Children” and "Restavecs" in Haiti', in Joy Moncrieffe \& Rosalind Eyben (eds.), The Power of Labelling: How People are Categorized and Why it Matters, London: Earthscan, pp. 80-96.

Montgomery, Heather (2000) 'Abandonment and Child Prostitution in a Thai Slum Community', in Catherine Panter-Brick \& Malcolm T. Smith (eds.), Abandoned Children, Cambridge: Cambridge University Press, pp. 182-98.

Morrow, Virginia (2001) ‘Using Qualitative Methods to Elicit Young People’s Perspectives on Their Environments: Some Ideas for Community Health Initiatives', Health Education Research, 16 (3), pp. 255-68.

Nieuwenhuys, Olga (1996) ‘The Paradox of Child Labor and Anthropology', Annual Review of Anthropology, 25, pp. 237-51.

Nieuwenhuys, Olga (1994) Children's Lifeworlds: Gender, Welfare and Labour in the Developing World, London: Routledge.

Nieuwenhuys, Olga (1995) 'The Domestic Economy and the Exploitation of Children's Work: The Case of Kerala', The International Journal of Children's Rights, 3(2), pp. 213-25.

Pande, Rajendra (1991) Street Children of India: A Situational Analysis, Allahabad: Chugh Publications.

Panter-Brick, Catherine (2002) 'Street Children, Human Rights, and Public Health: A Critique and Future Directions', Annual Review of Anthropology, 31, pp. 147-71.

Panter-Brick, Catherine; Smith, Malcolm T. (eds.) (2000) Abandoned Children, Cambridge: Cambridge University Press. 
Patel, Sheela (1990) 'Street Children, Hotel Boys and Children of Pavement Dwellers and Construction Workers in Bombay: How They Meet their Daily Needs', Environment and Urbanization, 2(2), pp. 9-26.

Phillips, W. S. K. (1994) Street children in India, Jaipur: Rawat Publications.

Platt, John T. (1884) A Dictionary of Urdu, Classical Hindi, and English, London: W.H. Allen.

Posner, Marc (2000) 'Hungry Hearts: Runaway and Homeless Youth in the United States', in Roslyn Arlin Mickelson (ed.), Children on the Streets of the Americas: Globalization, Homelessness and Education in the United States, Brazil and Cuba, London: Routledge, pp. 247-56

Pouchepadass, Jacques (1999) Champaran and Gandhi: Planters, Peasants, and Gandhian Politics, Oxford: Oxford University Press.

Prakash, Gyan (1990) Bonded Histories: Genealogies of Labor Servitude in India, Cambridge: Cambridge University Press.

Raffaelli, Marcela (1997) 'The Family Situation of Street Youth in Latin America: A Cross-national Review', International Social Work, 40(1), pp. 89-100.

Raffaelli, Marcela, et al. (1995) 'HIV-Related Knowledge and Risk Behaviors of Street Youth in Belo Horizonte, Brazil', AIDS Education and Prevention, 7(4), pp. 287-97.

Raffaelli, Marcela, et al. (1993) 'Sexual Practices and Attitudes of Street Youth in Belo Horizonte, Brazil', Social Science Medicine, 37(5), pp. 661-70.

Ribeiro, Moneda Oliveira; Ciampone, Maria Helena Trench (2001) 'Homeless Children: The Lives of a Group of Brazilian Street Children', Journal of Advanced Nursing, 35(1), pp. 42-49.

Roy, Ananya (2003) City Requiem, Calcutta: Gender and the Politics of Poverty, Minneapolis: University of Minnesota Press.

Scheper-Hughes, Nancy (1992) Death Without Weeping: The Violence of Everyday Life in Brazil, Berkeley: University of California Press.

Scheper-Hughes, Nancy; Sargent, Carolyn (eds.) (1998) Small Wars: The Cultural Politics of Childhood, Berkeley: University of California Press.

Scheper-Hughes, Nancy; Hoffman, Daniel (1998) 'Brazilian Apartheid: Street Kids and the Struggle for Urban Space', in Nancy Scheper-Hughes \& Carolyn Sargent (eds.), Small Wars: The Cultural Politics of Childhood, Berkeley: University of California Press, pp. 352-88.

Scheper-Hughes, Nancy (2005) 'Dangerous and Endangered Youth: Social Structures and Determinants of Violence', Annals of the New York Academy of Science, 1036, pp. 13-46.

Sen, Satadru (2005) Colonial Childhoods: The Juvenile Periphery of India, 1850-1945, London: Anthem.

Seth, Rajeev; Kotwal, Atul; Ganguly, K.K. (2005) ‘Street and Working Children of Delhi, India, Misusing Toluene: An Ethnographic Exploration', Substance Use and Misuse, 40(11), pp. 1659-680.

Veale, Angela; Taylor, Max; Linehan, Carol (2000) 'Psychological Perspectives of "Abandoned" and “Abandoning” Street Children', in Catherine Panter-Brick \& Malcolm T. Smith (eds.), Abandoned Children, Cambridge: Cambridge University Press, pp. 131-45.

Voluntary Health Association of India (2002) Seen, But Not Heard: India's Marginalised, Neglected, and Vulnerable Children, New Delhi: VHAI.

Wilkins, William Joseph (1882) Hindu Mythology, London: Thacker, Spink \& Co. 
Worthman, Carol M.; Panter-Brick, Catherine (2009) 'Homeless Street Children in Nepal: Use of Allostatic Load to Assess the Burden of Childhood Adversity', Development and Psychopathology, 20 (1), pp. 233-55.

\section{NOTES}

1. I place usually in parentheses because many 'street children' end up on the street because they are enslaved or 'trafficked' out of the village, and then run away from their traffickers; and though my central concern in this essay is with runaways who have made a choice to flee some unsuitable element of life in their villages, I also accommodate in this discussion the strategic use of names among their orphan, enslaved, and street-working cognates and comrades.

2. It is interesting in this sense to think of the re-named street child truly as a new incarnation, a newly fashioned self: the term avātara indeed is derived from the root $t r / t a r$, which refers to crossing (downward, as in descent); these children have not crossed a boundary between physical lives (though many have come close), but rather a boundary between conceptual lives, a feature of which is certainly a true starting-over.

3. It is notable that the place called Banta and the district called Tata Nagar is now as it was already then in the state of Jharkhand, a mineral-rich, conflict-plagued administrative unit whose birth in 2000 was related in part to 'adivasi' and 'tribal' politics.

4. 'Jhuggi' denotes a thatch hut, tent, or temporary dwelling, generally inhabited by poor and itinerant classes. The child has also taken on the name of the temple that characterizes his village.

5. He uses the English word 'death' here, embedded in his Hindi.

6. NSF-BCS 0942506

7. See Prakash (1990) on coolies and bonded labor in and from India.

8. Curiously enough, this individual appeared globally in the news, including the BBC, some years later (2010-2011) as a kind of curiosity-in the context of his former street childhood-for having moved to Atlanta after marrying in his home village a Cuban-American woman he had met in Delhi on the NGO's City-Walk tour. I am not able to ascertain whether or not he remains in the US.

9. As in, say the Manusmriti (56, Bhagavata Purana, xi. 5-11). Kapala-patra-nirata/Kangkala-malyadharini. The 'garland of bones' is associated with Shiva, who in the text is described as 'wearing a Brāhmanical thread composed of white snakes, clad in an elephant's hide, with a necklace of beads, and a garland of skulls, riding upon Nandi, accompanied by ghosts, goblins, spectres, witches, imps, sprites and evil spirits' and elsewhere, in a smear by Daksha, as follows: 'He roams about in dreadful cemeteries, attended by hosts of ghosts and sprites, like a madman, naked, with dishevelled hair, wearing a garland of dead men's [skulls] and ornaments of human bones' (as in Wilkins 1882).

10. Brunner, in a personal communication, further writes: 'The Persian word āwāra (Tehran: $\bar{a} v \bar{a} r e)$ is certainly common in Iran. It is already in early New Persian, in the Shahnama of Ferdowsi ('lost, in flight, vagabond,' Fritz Wolff, Glossary..., pp. 35-36). Both āwār and āwāra occur in medieval literature (examples in Dekkhoda, Loghatnāma, fascicle Ā-Abu Sa'd, Tehran, 1946, pp. 196-97). I don't recall it in Pahlavi or Manichean Middle Persian, and it is not in DurkinMeisterernst's dictionary. Although I don't have an etymology, for the morphology, cf. Mid/New Pers. āwāz 'voice,' āwām 'time period,' Pahl. and Jewish Persian āwādag 'generation' (according to Mackenzie, Dict. of Pahlavi, p. 13). Confusingly (or, for a poet, pleasingly) similar is wīrān (Pahlavi awērān) 'ruined, destroyed'-a meaning given by Dehkhoda for some examples.'

11. In India, where, for example, skin-whitening creams are marketed to dark-skinned women, and lighter pigments are often highly valued, skin-color acquires its meanings in a fraught 
calculus obliquely complicated by pre-modern histories of the Indo-Iranian interaction with the autochthonous groups that were eventually identified with the mlechha and impure castes, by colonial-era significations of white skin, and by the global circulation of images equating whiteness with wealth and prestige. All these blurry historical formations of phenotype may be then further consciously deployed by various interested parties.

\section{ABSTRACTS}

In India, child runaways inhabiting urban space mobilize a complex set of naming strategiesboth for themselves as individuals and for the category of person to which they see themselves belonging-as a component of strategies of evasion, dissimulation, and self-protection. In this widely-replicated mode of narrative praxis, iterated in similar ways throughout the Subcontinent (and beyond), personal names as deployed by 'street children' become fluid vehicles of strategic self-positioning to circumvent forms of power that seek to define, fix, and track the children. As any agent in public space threatens to temper their mobility and freedom, and potentially to make their location known to forces they wish to evade, these runaways may use dozens of names. The names are not used in unpatterned ways, but rather they are situationallycontingent.

\section{INDEX}

Keywords: India, street children, runaways, cities, Delhi, postcoloniality

\section{AUTHOR}

\section{JONAH STEINBERG}

Associate Professor of Anthropology, University of Vermont 